\title{
The Strategy To Translate Metaphor
}

\section{Yunita Widiyantari}

ABA Harapan Bangsa Surakarta

Jl. Pakel, Sumber Surakarta

Yunita_widiantari@yahoo.com

\begin{abstract}
Metaphor is called as part of comparison figure of speech. It compares two thing implisitly without using any comparison words such as, like, resemble to, etc. As a figurative expression, metaphor requires a special treatment to translate. The ability of the translator is very much influence to the result of metaphorical translation. He is not only have to empower himself with both source and target languages but also he better has a deep cultural understanding especially about metaphor. There are four types of metaphor on Ullmann version (1972: 213 - 216), namely: Antropomorfis etmaphor, animal metaphor, the abstract to concrete transfer and vise versa, sinaestetic metaphor. Furthermore, there are three criteria that should be fulfilled to value the quality of a translation viz the accuracy, the acceptability, and the text readability.
\end{abstract}

Keywords: Translation, Strategy, Metaphor

\begin{abstract}
Abstrak
Metafora disebut sebagai bagian dari perbandingan majas/gaya bahasa. Ia membandingkan dua hal secara tersirat tanpa menggunakan kata-kata perbandingan seperti "like"(seperti), "resemble to"(mirip dengan), dll Sebagai ekspresi figuratif, metafora memerlukan perlakuan khusus dalam menerjemahkan. Kemampuan penerjemah sangat banyak berpengaruh
\end{abstract}


terhadap hasilt erjemahan metafora. Dia tidak hanya harus memberdayakan dirinya dengan kedua bahasa sumber dan bahsa target bahasa tetapi juga ia harus lebih memiliki pemahaman budaya yang mendalam terutama tentang metafora. Ada empat jenis metafora menurut/versi Ullmann (1972: 213-216), yaitu: metafora Antropomorfis, metafora ke-binatang-an, perubahan dari abstrak ke konkrit dan sebaliknya ,metafora sinestetik. Lebih lanjut, ada tiga kriteria yang harus dipenuhi untuk menilai kualitas sebuah yaitu ketepatan/akurasi terjemahan, akseptabilitas, dan keterbacaan teks.

Kata Kunci: Penerjemahan, Strategi, Metafora

\section{Introduction}

To be a translator becomes the idea of many people. The working opportunity of a translator today is so wide since there are huge demands of translating. Nevertheless, the duty of a translator is not a piece of cake to do. A translator must be able to accomplish the translating process carefully. The professional one will understand his heavy assignment vis transferring the message from the source language to the target language. He also has to consider the whole context of the text in the way of form, language style, structure, texture, register, the naturalness level and the readability level.

Translation is an activity of transferring meaning from the source language into the target language. Many experts give their definitions about translation. It was Pinchuck (in Soemarno, 1988:28) who was simply defined translation as a meaning transferring. A deeper opinion was revealed by Brislin (1976:1) that "Translation is the general term referring to the transfer of thoughts and ideas from one language (source) to another (target) whether the languages are in written or oral 
form".

According to Brislin, translation is a general term that refers to the transfer of idea or thought from the source language to the target language either written or spoken. Therefore the core of translation is the transforming of message, meaning or idea from the source language to the target one. Whereas, in the term of language style, both languages used must be appropriate each other so that it will give the same effect between the reader of the source text and the reader of the translation version. That is because the resulted translation is accurate, understandable and acceptable.

Meanwhile, Catford (1974:20) stated that "Translation may be defined as the replacement of textual in one language (SL), by textual material in another language". In this definition translator will only change the text material or the passage in source language into the target language. Besides, in the real activity translator will not only transfer the substance material but he also has to consider the language style and the culture. Nida and Taber (1974:14) mentioned that "Translation consists of reproducing in the receptor language and secondly in terms of style". It means that translation is the re-expression into target language from the source language, with first focus on the meaning expression and then the style of the expression as the second.

The mastery of the culture and both languages used is not a guarantee that someone can be a qualified translator. Many requirements have to be possesed. Bell (1991:36) said "The translator must, as a communicator, possess the knowledge and skill." It means that a translator should have a wide deep insight and also skill. Furthermore, he has to master the translation theory and also has an understanding about 
the types of translation. Bell also revealed that “...the professional (technical) translator has access to five distinct kinds of knowledge: target language (TL) knowledge; text-type knowledge; source language (SL) knowledge; subject area ("Real-world") knowledge and contrastive knowledge."

In doing the process of translation, a translator does not only transfer the meaning. There are several aspects that should be taken into consideration. Those are linguistics and non linguistics aspects. In translation there are two terms vis linguistics unsure and extra linguistics unsure. Linguistics unsure is the language itself. It conveys word, phrase, sentence, paragraph and passage. While the extralinguistics is the unsure outside those above that are social context (register) and cultural context (genre).

In addition, term is an important substance for the translator to be mastered. In certain field of studies, a similar term will have a far meaning. The word "struktur" for instance, in language field it will be replaced by the word "grammar" but in technical field the word "structure" has always been related to shape or even building. A translator who is not accustomed to the various type field of studies will find it difficult to produce the best translation.

Another thing that could not be forgotten by a translator is the process of translation. According to Nida (1974) it comprises three steps vis analysis, transfer and restructuration. Nababan (2003:24) states that a translation process is a series of activities done by a translator when he transfers the message from the source laguage to the target language. Briefly, a translation process is described as follow:

1. The analysis of the source language text 
It is done by reaading the translated text over and over again. The purpose of the reading is that the translation will understand the entire text content both in terms of linguistics and extra linguistics substances. The linguistics substance refers to all that deals with language whereas extra linguistics substance is the opposite, it is anything outside the linguistics subjects. It is commonly related to the socio cultural of the source language text which is unseparatable to the language itself.

\section{Transferring}

It is a meaning searching or the transfer of meaning from the source language to the target language. Actually it is a mental process done by the translator. It is occured in the translator's mind. After he has the content, the meaning and the message of the text he then describes it into the target language written or orally.

\section{Restructurisation}

The last step of translation process is the restructurisation. This is the step where the translator acts to change the style form of the text into the style that matches to the style of the target readers or listeners. $\mathrm{He}$ will pay more attention to determine the language style such as whether the formal or informal style, the scientific style, poetic, play or novel or others which is suitable to the text being translated. Moreover, the translator also take into consideration the reader design or for whom the text translates for. It is because the choice of words that used in children text is very much different to the dixtion used for adultary readers.

In addition to the steps above, there is usually something that influences the translation process but a translator does not realize it. That is the ideology of the translator. It will really take an important effect to 
the result of the translation. As the main actor, translator has the right to take the decision to any words or phrases used. In doing this, his ideology is always be a shadow that influences his job.

According to Hoed (2004: 1) especially in the text that has cultural content, a translator is always influenced by his certain ideology. In fact, any text must contain cultural substance either large or little in the ammount. It is because a text is described through language and language is part of a culture. Therefore, to produce an accurate, understanable and acceptable translation, it is not enough to only analys the source language text. The factors outside the translation text is also important to be accounted. Those factors are:

1. The text writer

To produce a writer, a text writer can not be free from the influence of his educational and social background. Every thought and every word he gives to the translation is a reflection of his personnal background.

\section{The translator}

Translator is someone who connects two languages involved in the translation process. It is hopefully that he is able to determine words or terms or even sentences that will be used or omitted. This is because the translator is the person who receives the text in source language and he also will have to transfer his production in the target language precisely.

3. The reader

The readers will finally give their assesment to a translation. This mark will show whether the translation is qualified or not. 


\section{The norm difference}

The norm in one place can have different standart to the norm in other places. So that it is important for the translator to pay attention to this matter due to any norm contravention in a source text or even in a translation.

5. The culture

The different cultures of both language can cause a translation product to be less comprehenable. Therefore it is a must for a translator to have a wide insight about the both cultures involved in the translation process. This deep understanding will very much help him in determining the meaning inside any cultural terms appearred in the translation.

6. The topic of the talk

It is necessary to pay more attention to the topic of the talk. It will lead to the comprehension of a text by the translator, text writer and the translation readers. The mastery of the main material and the theme being disccused included the specific terms that come up in the text is very important to be understood.

An incompleteness understanding about the material being translated will cause difficulties in the translation process. Nonetheless, the complete and sufficient understanding about what a good translation is and what should do to produce a best qualified translation must be done to result in an accurate, acceptable and readable translation.

From those definitions of translation given by several experts, it can be concluded that translation is an activity of transferring message from the source language to the target language by still focus on the text type, the style of the language used and the culture. The translator, 
therefore, has to consider both linguistics and extra linguistics aspects.

\section{Discussion}

Metaphor and the strategy in translating metaphor Metaphor

Metaphor is called as part of comparison figure of speech. It compares two thing implisitly without using any comparison words such as, like, resemble to, etc. The use of language that contain metaforical speech commonly found on literature works such as poetry or songs. Edi Subroto (1991: 45) gives his opinion that metaphor is a configuration of linguistics creative power in the meaning application.

Ulmann (1972: 213 - 216) said that metaphor is created under the grounded on the similarity between two things or two terms that are the thing we are talking about and that to which we are comparing with. The first thing is called tenor and the second one is called vvehicle. Metaphor is formed under certain factors. Still according to Ullmann those factors are because of a particular motivation, a certain emotional encouragement (to an intense emotional expression), to overcome the vocabulary lackness, to concrete something abstract, et cetera

The effectiveness of a metaphor depends on the distance of tenor and vehicle. If the distance is too close, metaphor is not interesting anymore because the similarity is so real that people do not take a good care of its conotation. For example kuping gajah dan lengan kursi. We recognize kuping gajah as a name of a kind of snack which shape is like the ear of an elephant. The similarity collides each other that makes the metaphor sounds ineffective. Moreover, the metaphor lengan kursi shares the same thing with the previous model. Lengan or shoulder in English is 
part of human body which is assumed to have the same shape to a part of chair that is the shoulder of the chair. The near similairity of the above examples results to the an uninteresting metaphor. This metaphor is called as the dead metaphor. The kuping gajah and lengan kursi expressions have been a cliche in Indonesian language so that the relation between tenor and vehicle is not an amazing topic to be disccused.

When the similarity of two substances in metaphor is vague, however, it will take the metaphor into an effective metaphor or called as the living metaphor (1972: 213-216). We can take the example of the sentence Mobilnya batuk-batuk sejak tadi pagi. The phrase batuk-batuk is not suitable to put aside other lingual unities in that sentence. Certainly it is impossible for a car to get cough like what human being do. The meaning deviation that appeared here will create a living metaphor.

There are four types of metaphor on Ullmann version (1972: 213 216), namely:

a). Antropomorfis metaphor.

It is a kind of metaphor that source to part of human being body or the characteristics of human being which then relates to unliving things such as kaki meja or mulut gang. The similarity that emerges on the examples above is on the position. Kaki meja or the leg of the table is part of the table which is used to support the table to stand up. It is together with the function of a leg which is also to stand the body up. In addition, mulut gang is the most outside part of an alley. It is practically used as a way to come inside or outside the area. Sure, it also shares the similarity to human's mouth which is an outside body part that is used to take food inside the human's bod. These examples are taken from Harry Potter and The Chamber of Secrets novel and the translation in the Harry 
Potter dan Kamar Rahasia.novel.

He was scrambling back onto the chest of drawers when Uncle Vernon hammered on the unlocked door---and it crashed open.

Dia sedang memanjat lemari lacinya ketika Paman Vernon menggedor pintu yang sudah tidak terkunci---dan pintu berdebam terbuka.

Antropomorfis metaphore is in the above sentence particulary in the the chest of the drawer phrase. The use of word chest which is part of human body is compared to drawers (laci) word that considered to hace a chest likes what human have. Another example will make us more understand this theory.

Led by Fawkes, whose wide scarlet wings emitted a soft golden glow in the darkness, they walked all the way back to the mouth of the pipe.

Dipimpin Fawkes, yang sayap merah lebarnya mengeluarkan cahaya lembut keemasan di dalam kegelapan, mereka berjalan kembali ke mulut pipa.

The phrase the mouth of the pipe tries to compare part of human body that is mouth (mulut) with pipe (pipa), an unliving thing. The similarity of shape and function becomes the comparable point of similarity in the above sentence.

b). Animal metaphor

That is if the source of the metaphor comes from the animal world for instance leher angsa (part of toilet equipment) or kumis kucing (a kind of plant), telur mata sapi (omellete), tulisan cakar ayam (chicken hand writing), tenaga kuda (horse power) et cetera. Animal vehicle is used in several speech acts such as verb, noun or adjective. The usage of animal as the vehicle is since it has a resemblance characteristics in the 
way of form and function. Look at an example taken from Harry Potter and The Chamber of Secrets novel and the translation in the Harry Potter dan Kamar Rahasia.novel.

Aunt Petunia was horse-faced and bonny; Dudley was blond, pink, and porky.

Bibi Petunia kurus berwajah kuda. Dudley berambut pirang, kulitnya agak merah jambu, jadi kesannya seperti babi.

The sentence uses horse-faced phrase to compare aunt Petunia face with horse $(k u d a)$. In the novel, it is described that this Harry Potter's aunty has a thin body that her face looks so haggard and looks like horse face. In addition, the word porky is used by the writer as a metaphor to describe Dudley, Harry Potter's cousin, who is fat and has fair pink complexion likes a pig.

c). The abstract to concrete transfer and vise versa

The third metaphor is a metaphor which appearred as the result of the transfer of a concrete to an abstract experience and vise versa from an abstract to a concrete thing. Some examples of this metaphor are highlight and bintang lapangan (fieldstar). In this type, there are many abstract objects used as vehicles and then they are concreted in the metaforical meanings. In the word for word translation, the word highlight means an abstract bright gleam though its metaforical meaning is the main happening. This word is often used to emphazise the main news that showed in newspaper or on TV. So is the word fieldstar. Metaforically it is used to show an amazing achievement and performance and it does not merely refer to an athlete who becomes the idol in such games. From Harry Potter and The Chamber of Secrets 
novel and the translation in the Harry Potter dan Kamar Rahasia.novel we learn this metaphorical transfer.

The moment the door had closed, Mr. Borgin dropped his oily manner

Begitu pintu tertutup, Mr Borgin menanggalkan sopan santunnya

In the above sentence, the transfer appearred from concrete thing viz dropped word to an abstract phrase that is his oily manner. Manner or etiquette in bahasa Indonesia is something that absolutely abstract. So it is impossible to treat it such as drop or lift it. The use of the concreteabstract metaphor to this sentence is able to give a language variation so that the resulted sentence becomes more lovely and attractive. In the sentence below, the transfer of experience that happens is the the transfer from the abstract to concrete thing. Here is the sentence.

Darkness was falling as they walked down to Lockhart's office.

Kegelapan sedang turun ketika mereka berjalan menuju kantor Lockhart.

The word darkness (kegelapan) certainly is something abstract. It is then compared to a verbal phrase was falling which is a concrete thing. d). Sinaestetic metaphor

Sinaestetics metaphor is a kind of metaphor that is created based on the transfer of conceptions or senses. It might be the transfer of one human being sense to another. As the example is the transfer of hearing sense to the feeling sense which resulting metaphor such as suaranya halus (her nice voice), musiknya lembut (the soft music), kata-katanya manis (his nice words), kerasnya kehidupan (the hard life), and so on. Let's play atention to these examples. 
From behind him, Harry could hear a funny rustling and clicking.

Dari belakangnya, Harry bisa mendengar bunyi berkeresek dan klak-klik yang aneh

The last sentence uses sinaestetic metaphor in the a funny rustling and clicking phrase. The word funny (lucu) is parallized or compared to the word rustling (gresak-gresek yang dihasilkan oleh suara kertas yang bergerak) and clicking (dentang-denting suara gelas). Thus, there is a sense transfer that is from feeling sense to the hearing sense. Another example of the use of sinaestetic metaphor is as follow:

There was an odd red gleam in his hungry eyes now.

Ada kilat merah aneh di mata Riddle yang kelaparan.

The word hungry is usually connected to a stomach condition that needs to be fulfilled or starves. But interestingly, in this sentence the word hungry is compared to the word eyes which do not have a specific relationship to stomach condition since eyes capacity is as sight sense.

\section{The startegy in translating metaphor}

As discussed previously, metaphor is part of figurative expressions. Inside metaphor there is cultural content that should be translated. This, however, will rise the possibility that there will be an untranslatability condition. It is because the translator will not only consider the both languages used but also the both cultures appearred. Related to this translation difficulty due to the culture, Larson (1984:137) stated that 'One of the most difficult problems in translating is found in the differences between cultures'.

The difficulty faced by the translator in relation to metaphor 
translation is because usually the translator does not really recognize that metaphor is actually being utilized in the translated text. Hence, he tends to translate the text literally without paying attention to the metaphor aspects.

In order to produce an ideal translation, a translator should empower himself with any knowledge and substances that cover the process of translation. Those substances are linguistics and extra linguistics substances. Linguistics substancee is the language substances inside the translated text like word, phrase, sentence, paragraph and even passage. Whereas the contents of extra linguistics substance are those outside the linguistics substances such as social and culture contexts and the style of the language.

A translator often faces several difficulties in finding the proper meaning or at least the closest meaning to the words, phrases or sentences being translated when he discovers figurative expressions whether in the form of metaphors or proverbs. Meanwhile, in the translation view, the beauty that appearred in the sourse language text due to the the use of certain language style should be transfered as lovely as it is in the target language text. The formal language style is not proper to be transfered in a relax style.

Moreover, the conversational style is not also suitable to have a speech language style. The miss-equivalent translation will result to a rigid translation or the worst is that the translator will create a missconception about the text. A translator is strived for determining an exact equivalent based on the contexts surround it. A translator has to see figurative expressions such as metaphor, idiom and proverb in the both languages involved in order to avoid deviation of meaning in translation. 
The translation experts admit that they often have to work extra harder when they translate texts that contain figurative expressions. Metaphor is always be a problem that have to be solved by the translators. It is because metaphor cannot be translated literally and has a high level of difficulty in the process. In his book, Meaning-Based of Translation, Larson (1984: 293) said that if metaphor is translated literally or by word for word method, the translation result will often contain misperception. The problem is due to the cultural substance of the society who speak in the source language is not always the same to the culture of the target language.

Moreover according to Larson (1984: 17) there are some reasons why it is difficult to translate metaphor and why it cannot be translated literally. Those are:

a. The image used in the metaphor is not recognized in the target language.

b. The topicc of the metaphor is not clearly explained.

c. The point of similarity is implicit and difficult to be recognized.

d. The point of similarity can be interpreted differently depend on the culture.

e. There is no comparison for the metaphor in the target language as their existences in the source language.

f. Every language has their differences in the frequency of using metaphor and also the difference in the way they are created.

Remembering that the main purpose of translation is to re-express the content and the message from the source language to the target language in terms of meaning and style to gain a qualified translation, it is important to not only have a deep understanding about the two 
languages used but also the understanding of cultural contexts of those languages involved.

In translating metaphor, it is important to look at the point of similarity between the languages involved in the translation process. Larson (1984: 276) gave an example in the sentence "He is a sheep". In several cultures this sentence has different meanings based on the its local cultural context. It can be translated as a person who just follows without thinking or in other culture that sentence is translated as a young fellow waiting for girls to follow him, and many more.

To overcome this phenomena Larson (1984: 276) mentioned five ways to translate metaphor as follow:

a. The metaphor is maintained. This method is used when the metaphor looks clear and natural for the readers.

b. The metaphor can be translated as simile by adding some words such as like, as if, resemble and so on.

c. The metaphor of the source language is transfered to the metaphor in the target language which has the same meaning.

d. The metaphor will be maintained by explaining the meaning or adding the topic of the talk or the point of similarity.

e. The meaning of the metaphor is explained without using its metaforical image.

Almost similar to Larson's opinion, another expert, Newmark (1981: 88-91), proposed seven manners to translate metaphor, namely:

a. To reproduce the same image in the target language. It has a certain requirement that is the image used has a propotional frequency and usage in the appropriate style. 
b. To change the image in the source language into a standart image in the target language which is not contrast to the target language culture but as metaphor (stock metaphor), proverb et cetera.

c. To translate metaphor with simile by maintaining the image.

d. To translate metaphor or simile with simile but by adding the meaning or sometimes translate metaphor with metaphor plus the meaning.

e. To change metaphor to be a meaning.

f. To omit it. When the metaphor is up side down or unneedfull the translator can omit it with the meaning component.

g. To combine the metaphor with the meaning

In relation to both solutions given by Larson and Newmark, a translator will be easier to do his job especially when he meets any text with metaphor content. Those opinions above can be a guideline for a translator to transfer the exact message and meaning of the metaphor texts. The border and limitation are clear enough to support a translator to overcome his problem that usually come in translating metaphor.

\section{Assessing the quality of translation}

Assessing the quality of a translation is done to jugde "how good" a translation is. It also means how to criticize a translation work.. To be able to criticize someone has to have a wide knowledge and ability. Schutlle in Nababan (1997: 76) said that there are several ccriteria to be a translation work critic. He must master the source and target languages. He also has to understand the difference of linguistics perception in both source language and target language. In addition he has to be very familiar to the aesthetics of those two languages. Finally he has to have a 
deep wide knowledge about the material he is criticizing

In relation to this translation assessment, Larson (1984:482) mentioned that a translation should be evaluated to ensure the level of accuracy, the clearity and also the naturalness it got. Meanwhile according to Nababan (2003:86) a research about translation quality comprises three things, namely: (1) the accuracy of the message transfer, (2) the accuracy of message expression in target language, and (3) the naturalness of the translation language. As a consequence of both opinions above, there are three criteria that should be fulfilled to value the quality of a translation viz the accuracy, the acceptability, and the text readability.

\section{The accuracy}

The accuracy of a translation is related to how deep the content of the source language text is correctly transferred in the target language (Nababan, 2004:61). When a message from the source language is well and exactly delivered in the target language it is said that the translation has covered the accurate substance. An accurate translation is a translation that is far from language mistake and also be able to communicate its content from its former language to the new one precisely. Many translators keep their translations accurate by positioning themselves more in the source language side. When the translation is not accurate it will turn to less or even in-accurate.

In metaphorical translation, a translation is classified into accurate when the metaphorical meaning in the target language can be transferred precisely in the metaphorical meaning in the target language. Furthermore, when the point of similarity in the source language 
metaphor is found and used in the target language metaphor with the same meaning then this translation is named as accurate. With such limitations, translating metaphor sounds more difficult to do and it will be a challenge for the translators.

\section{The acceptability}

A good translation is translation that acceptable by the target language readers. Acceptability requires that a sequence of sentences be acceptable to the intended audience in order to qualify as a text (Rekmana in Yuwono, 2005:53). It means that the acceptabilit has a tight relation to the text readers aspect.

When reading a text, a reader tries to comprehend it best. He will understand every single sentence that builds the text. He will also connect the understanding that is developed from the series of sentences that must be in associated to its situational context. If then the readers find any sentences which is miss to the undestanding given and are unusal in their language, it means that text is not the acceptable one.

The acceptability aspect also values the logical side of a translation in the target language. A simple example of an unacceptable translation in target language is on the sentence I cut my finger. The translation in Indonesian Saya memotong jari saya is accurate. However, the sentence is unacceptable because it is not logic for someone to cut his own finger on purpose. The acceptable translation to this is Jari saya terpotong. There is an accidental element happened there which causes someone's finger cut.

A metaphor translation is considered acceptable if the meaning or message in the target text metaphor is well understood by the target 
laguage readers. Therefore, if the image in the source language metaphor appeared and used with the same meaning to the image of target language metaphor, the metaphorical translation is belong to acceptable. Here is another simple example for us. In the west world, a cat is considered as the second level animal after dog. Cat does not give a significant contribution in the way of loyalty, hard working and safety as given by a dog. As the result, in west culture dog is much more valuable than cat.

The difference between west and east cultures takes part here. The dog's image in the east, in contrast, is not as high as it is in the west. In several regions such as in Arabic or other Islamic countries dog's image is even so low and it is viewed as a disgusting animal. Religion perspective becomes the main reason for this matter. When a sentence "You worked like a dog" appearred, a translator should be able to see the situatioanal context of the target language first before he does his job. Certain values in the source language culture for dog such as hard working are not found in the east cultural context. Thus, it is inappropriate for the translator to translate it into Kau bekerja seperti anjing, eventhough the acceptable meaning of the sencente is Kau seorang pekerja keras or You are a hard worker. The translation of Kau bekerja seperti anjing is unacceptable in the target language.

The readability of the text

Richards et al in Nababan (2003: 62) mentioned Readability ...how easily written materials can be read and understood. It means that the readability is to measure how easy a text to be comprehend in the target language. When a text is fluently read and understood as if we understand its source text, this translation text is considered as having a 
high readability level. From the explanation above, it is clear that the readability level is separated from the accuracy and the acceptability level. It can be, sometimes happened, a text is comprehendable and easily read but it is not correct in the way of transferring the message.

\section{Conclusion}

In such a way, when a translator realizes the difficulty level and its chalange that he must face then translating metaphor is not an easy thing to do. The translation experts, indeed, have been thinking about certain strategies used to overcome the translating metaphor problems. Hopefully, while referring to the theories proposed by Larson dan Newmark above, it is better for the translator to give the best equivalent to the sentence containing metaphor.

\section{References}

Bell, Roger T. 1991. Translation \& Translating: Theory and Practice. New York: Longman Inc.

Brislin, Richard W. 1976. Translation: Application, and Research. New York: Gardner, Inc.

Catford, J.C. 1974. A Linguistic Theory of Translation. Oxford: Oxford Univ. Press.

Hoed, B.H. 2004. Ideology dalam Penerjemahan. JLB Vol. 2 No. 1 Tahun 2004. Hal 01-16. Surakarta: Program Studi Linguistik (S2) PPs Universitas Sebelas Maret.

House, J. 199. A Model for Translation Quality Assessment. Tubingen: TBL Verlag Gunter Narr.

Gibbs, Steen. 1997. Metaphor in Cognitive Linguistics. Amsterdam: Benjamins Publishing Company.

J.K. Rowling. 1998. Harry Potter and The Chamber of Secrets. New York: Scholastic Inc. SCHOLASTIC. 2000.Harry Potter dan Kamar Rahasia. Terjemahan Bhs 
Indonesia oleh Listiana Srisanti. Jakarta: Gramedia Pustaka Utama.

Larson, Mildred L. 1984. Meaning-Based Translation: A Guide to CrossLanguage Equivalent. America: University Press of America.

Nababan, M.R. 1997. Aspek Teori Penerjemahan dan Pengalihbahasaan. Surakarta.

2003. Teori Menerjemah Bahasa Inggris. Yogyakarta: Pustaka Pelajar.

2004. Strategi Penilaian Kualitas Terjemahan, Jurnal Linguistik Bahasa, Volume 2 No. 1. Mei 2004. Hal 54-65 Surakarta: Program Studi Linguistik (S2) PPs Universitas Sebelas Maret.

dkk. 2004. Laporan Penelitian: Keterkaitan Antara

Latar Belakang Penerjemah dengan Proses Penerjemahan dan Kualitas Terjemahan (Studi Kasus Penerjemah Profesional di Surakarta). Surakarta. Program Studi Pascasarjana Universitas Sebelas Maret.

Newmark, P. 1981. Approches to Translation. Oxford: Pegamon Press. International Ltd.

Nida, E.A. dan Ch. R. Taber. 1974. The Theory and Practice of Translation. Den Haag: Brill.

Rochayah Machali. 2000. Pedoman Bagi Penerjemah. Jakarta: Grasindo. Sadtono. 1985. Pedoman Penerjemahan. Jakarta: Pusat Pembinaan dan Pengembangan Bahasa Departemen Pendidikan dan Kebudayaan.

Soemarno. 1991. Berbagai Kesulitan dalam Penerjemahan. Konggres Bhs Jawa di Semarang. 1998. Sedikit Catatan Mengenai Teori Terjemahan. Seminar sehari bidang Penerjemahan. UNS. Surakarta.

2003. Menerjemahkan Itu Sulit dan Rumit. Konggres Nasional Penerjemahan, 15-16 September 2003, Fakultas Sastra dan Seni Rupa dan Program Pascasarjana Universitas Sebelas Maret Surakarta.

Stern, Josep. 2000. Metaphor in Context. Massachussets: Massachussets Institute of Technology.

Subroto, D. Edi. 1991. Metafora dan Kemetaforaan (Analisis pada Beberapa Puisi Indonesia). Majalah Ilmiah Haluan Sastra Budaya No. 17 Th. X. Oktober. Surakarta. UNS

Ullmann, Stephen. 1972. Semantics: An Introduction of the Science of 
Meaning. Oxford: Basil Blackwell.

Yuwono, Suhud Eko. 2005. Analisis Kesepadanan, Keterbacaan, dan Keberterimaan Teks Terjemahan Cerita Anak Terbitan Balai Pustaka: Kajian Terjemahan Istilah Budaya. Tesis. Surakarta: Universitas Sebelas Maret. 
